\title{
Expression of D-type cyclins in differentiating cells of the mouse spinal cord
}

\author{
Patricy de Andrade Salles ${ }^{1}$, Juliana Chagas Fortes ${ }^{2}$, Maria Izabel Florindo Guedes ${ }^{2}$ and Mathias Weller ${ }^{3}$ \\ ${ }^{1}$ Departamento de Medicina Veterinária, Universidade Estadual do Ceará, Fortaleza, CE, Brazil. \\ ${ }^{2}$ Departamento de Nutrição, Universidade Estadual do Ceará, Fortaleza, CE, Brazil. \\ ${ }^{3}$ Departamento de Biologia, Universidade Estadual do Ceará, Fortaleza, CE, Brazil.
}

\begin{abstract}
The D-type cyclins form complexes with the cyclin dependent (CD) kinases CDK4 and CDK6 and promote the G1-S phase transition of the cell cycle by antagonizing the retinoblastoma suppresser protein $\mathrm{pRB}$. In the developing nervous system D-type cyclins show spatially and temporally dynamic patterns of expression. We demonstrated that cyclin D1 was transiently expressed in differentiating spinal cord ventral interneurons while cyclin D3 protein was expressed in differentiating motor neurons and dorsal interneurons. This expression of cyclin D 3 in neurons of the mantle zone was extended to all regions of the spinal cord at E15.5. The results suggest that cyclin D1 and D3 have specific functions in differentiating neurons. Similarly, in the developing midbrain-hindbrain region the D-type cyclins were expressed in different subsets of cells. Our results argue in favor of different functions for D-type cyclins during proliferation and differentiation of neural progenitors.
\end{abstract}

Key words: cell cycle, D-type cyclins, midbrain-hindbrain region, neurogenesis, spinal cord.

Received: December 1, 2006; Accepted: April 23, 2007.

\section{Introduction}

The induction of D-type cyclins (cyclins D1, D2 and D3) by mitogens causes a close link between the core cell cycle machinery and the extracellular environment (Matsushime et al., 1991; Sherr, 1996; Sherr and Roberts, 1999). The D-type cyclins associate with the cyclin-dependent kinases CDK4 and CDK6 (Bates et al., 1994a; Meyerson and Harlow, 1994; Tam et al., 1994).

The D-type cyclin-CDK complex phosphorylates the retinoblastoma tumor suppressor protein, $\mathrm{pRB}$ and the $\mathrm{pRB}$ related proteins p107 and p130 (Bates et al., 1994b; Matsushime et al., 1994; Sherr and Roberts, 1999). This in turn allows the additional phosphorylation of $\mathrm{pRB}$ by cyclin $\mathrm{E}$ and cyclin A-cdk2 complexes leading to the release of the E2F transcription factors and thereby promoting the G1-S phase transition of the cell cycle (Adams and Kaelin, 1995, Lukas et al., 1995a,b; Adams and Kaelin,1996; Dyson, 1998).

During mouse embryogenesis the D-type cyclins show highly dynamic expression patterns in different tissues suggesting that unique promotor elements exist in the three genes (Agguzi et al., 1996). These expression patterns can be overlapping or exclusive in a specific tissue at a determined developmental stage. In the developing nervous

Send correspondence to Mathias Weller. Laboratório de Bioquímica Humana, Bloco D, Universidade Estadual do Ceará, Av. Paranjana 1700, Campus do Itaperi, 60740-000 Fortaleza, CE, Brasil. E-mail: mathiasweller@ hotmail.com. system, for example, only cyclin D2 is expressed in the cerebellar bud between embryonic (E) days 14.5 (E14.5) and E15.5, whereas cyclin D1 and D2, but not D3, are expressed in the subependymal zone of the telencephalon (Aguzzi et al., 1996). During neurulation the expression in the neuroectoderm is regulated along the anterior-posterior and the dorso-ventral axis resulting in distinct patterns for each D-type cyclin and segment specific patterns of cyclin D1 and D2 in the developing hindbrain (Wianny et al., 1998).

As all three D-type cyclins activate CDK4/6, originally they were thought to have redundant functions. This point of view was challenged by the observation that in mice expressing only one single D-type cyclin although this cyclin D is expressed ubiquitously it cannot substitute for the two missing D-type cyclins in all regions of the developing embryo (Ciemerych et al., 2002). For example, mice expressing only cyclin D3 lack normal cerebella while mice expressing only cyclin D2 present neurological abnormalities (Ciemerych et al., 2002). Previous studies have also revealed the expression of cyclin D1 and D2 in post-mitotic cells of the developing nervous system (Tamaru et al., 1993; Ross and Risken, 1994; Wianny et al., 1998; De Falco et al., 2004; Schmetsdorf et al., 2005; Schmetsdorf et al., 2006). These results suggest that the different D-type cyclins have specific functions in proliferating and differentiating cell populations during 
neurogenesis. Additionally, expression of D-type cyclins has been implicated in neuronal cell death associated with seizure, ischemia, stress and neurodegenerative diseases (Becker and Bonni, 2005; Hoglinger et al., 2007).

In the present study we analyzed potential functions of D-type cyclins in differentiating neurons of the developing mouse spinal cord and the midbrain-hindbrain region.

\section{Materials and Methods}

Pregnant female mice (Mus musculus) with a mixed 129SV/BL background were sacrificed according to institutional guidelines. Embryos were generated by timedmating, counting the morning after pairing as embryonic day 0.5. Antibody staining experiments on paraffin sections and in situ hybridizations on cryosections were performed as described by Weller et al. (2006). Primary antibodies against cyclin D1, D2 and D3 proteins were purchased from Dianova (DLN-12841; DLN-08380; DLN08391 and DLN-08401). The antibody against Lim1 protein was purchased from Chemicon (AB3200). The antibodies against Islet1, Islet 2 and $\operatorname{Lim} 3$ proteins were a kind gift from S. Pfaff and T. Jessel (Tsuchida et al., 1994; Shirasaki and Pfaff, 2002). The antibody against neurofilament was purchased from Sigma (N5264). Primary antibodies were visualized with $\mathrm{Cy} 3$ or Alexa conjugated secondary antibodies (Jackson Labs) and colorimetrically using the Envision ${ }^{\mathrm{TM}}+\mathrm{HRP}$ system (DAKO) according to the manufacturer's instructions. Possible cross-reactions of secondary antibodies were excluded by control experiments.

Images were collected using an Axiophot light microscope (Zeiss) in conjunction with a ProgRes 3008 (Jenoptik). Attachment and Image processing was performed with Adope Photoshop CS software.

\section{Results}

Cyclin D1, D2 and D3 showed different expression patterns in the spinal cord at the E10.5 and E12.5 stages. The results (Figure 1) were summarized in Table 1.

The expression patterns of cyclins D1 and D3 at the E12.5 stage were investigated to ascertain if they were associated with different cell types defined by the expression of patterning genes. To address this question double staining experiments against D-type cyclins and the proteins of patterning genes were performed. Lim1 is expressed in the lateral subdivision of the lateral motor neuron column and in ventral interneurons $\left(\mathrm{LMC}_{\mathrm{L}}\right.$; Ensini et al., 1998; Sockanathan and Jessel, 1998; Shirasaki and Pfaff, 2002).). It is possible to detect all postmitotic motor neurons with an antibody recognizing Islet1 and Islet 2 (Tsuchida et al., 1994; Pfaff et al., 1996). We found that Lim1 and cyclin D1 were co-expressed at high levels in ventro-lateral spinal cord cells in different regions along the rostro-caudal axis (Figure 2A, B, arrows). The cells expressing cyclin D1 were located in the spinal cord intermediate and mantle zones. To clarify if these cells were motor neurons or interneurons double stainings with Islet 1 and Islet 2 were performed. Ventral spinal cord cells expressing cyclin D1 at high levels never expressed Islet1 or Islet2 (Figure 2C), indicating that these cells were not motor neurons but ventral interneurons.

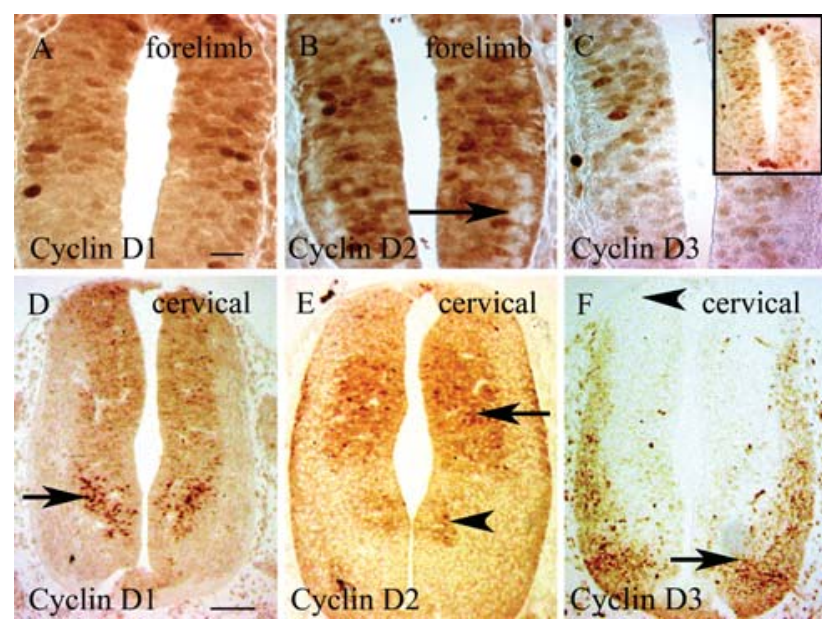

Figure 1 - Consecutive sections through the mouse spinal cord (SC) are shown. Protein expression of D-type cyclins at the E10.5 embryonic stage at the forelimb-level (A-C) and the E12.5 embryonic stage at the cervical level (D-F). (A) Cyclin D1 is expressed in all or most cells but at higher levels in the dorsal SC. (B) Although cyclin D2 shows equal expression levels in the majority of the $\mathrm{SC}$, the protein is missing in some mantle zone cells (arrow). (C) Cyclin D3 is expressed at higher levels in the dorsal spinal cord and at the highest levels in the floor plate and in a small cell population of the roof plate. (D) Expression of cyclin D1 in the ventricular and the intermediate zone. Highest protein levels are found ventrally (arrow). (E) Expression of cyclin D2 dorsally in cells of the ventricular and the intermediate zones (arrow) and at weak levels in a ventral cell population (arrowhead). (F) Expression of cyclin D3 in the mantle zone (arrow) is missing in the dorsal region (arrowhead). Dorsal on the top; Ventral at the bottom. Scale bars: In A, $50 \mu \mathrm{m}$ for A-C; In D, $50 \mu \mathrm{m}$ for D-F and the inlay of C.

Table 1 - 1. Expression of D-type cyclins in the developing mouse spinal cord. The number of plus symbols indicates the staining intensity $(+++>$ $++>+$ ) for each D-type cyclin in the spinal cord at embryonic stages E10.5 and E12.5.

\begin{tabular}{|c|c|c|c|}
\hline \multirow[b]{2}{*}{ Embryonic stages } & \multicolumn{3}{|c|}{ Cyclin } \\
\hline & D1 & D2 & D3 \\
\hline \multicolumn{4}{|l|}{ E10.5 } \\
\hline Dorsal spinal cord & +++ & +++ & ++ \\
\hline Ventral spinal cord & ++ & +++ & + \\
\hline Roof plate & +++ & +++ & +++ \\
\hline Floor plate & ++ & +++ & +++ \\
\hline \multicolumn{4}{|l|}{ E12.5 } \\
\hline Dorsal ventricular zone and intermediate zone & ++ & +++ & + \\
\hline Ventral ventricular zone and intermediate zone & +++ & ++ & + \\
\hline Dorsal mantel zone & + & + & ++ \\
\hline Ventral mantel zone & + & + & +++ \\
\hline
\end{tabular}



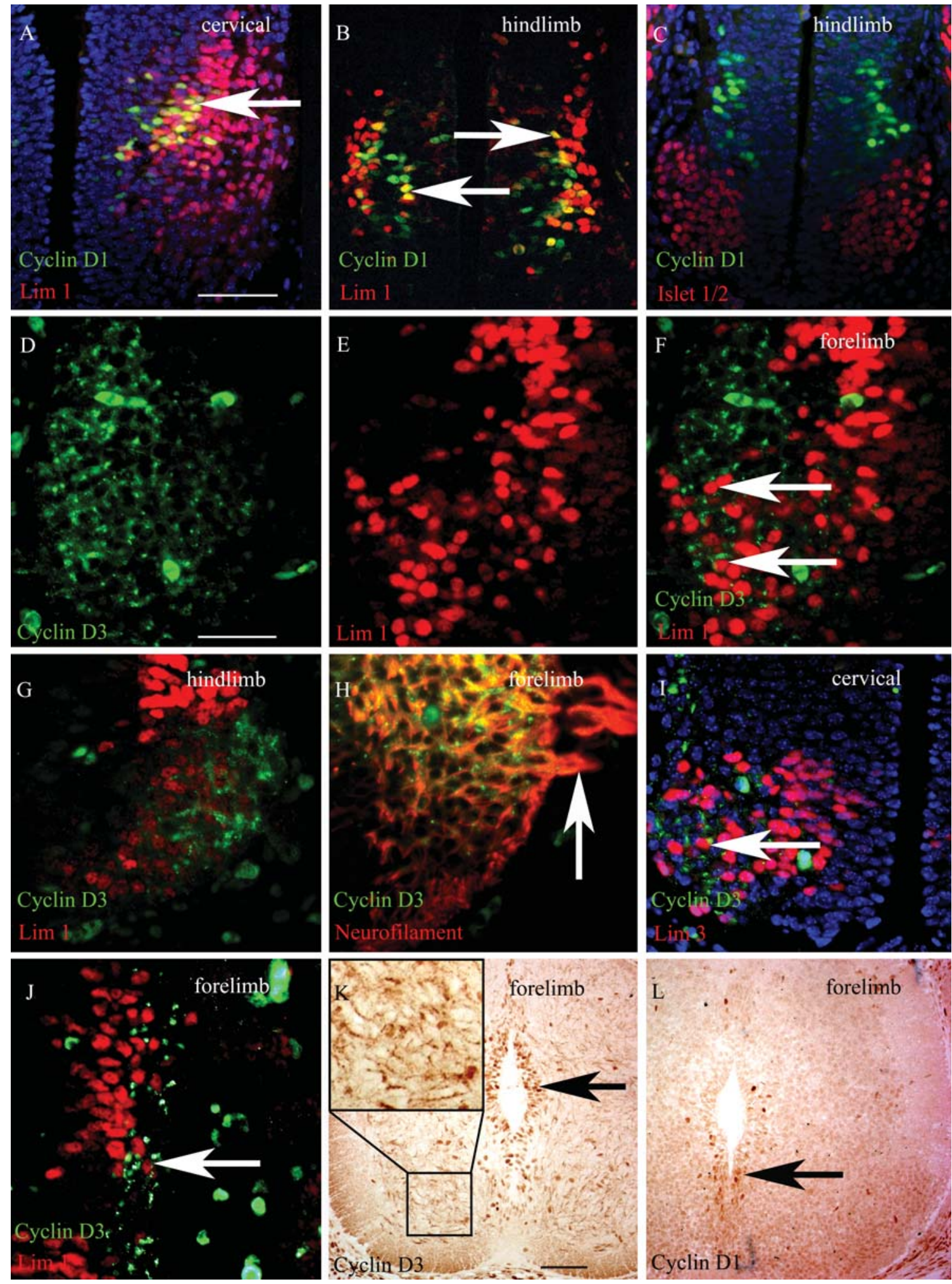

Figure 2 - Sections through the spinal cord (SC) E12.5 embryonic stage showing fluorescent staining (A-J) and through the spinal cord E15.5 embryonic stage showing colorimetric staining (K, L). (A-C) Cyclin D1 (green) co-localizes with Lim1 (red; A, B, arrows), but not with Islet 1/2 (red; C). (D-G) Cyclin D3 (green) is expressed ventrally in Lim1 (red) positive cells at the forelimb (D-F) and the hind limb level (G). In (F) the overlay of (D) and (E) is shown. (H) Cells expressing cyclin D3 show neurofilament (red) positive axon extensions typical of motor neurons (arrow). (I) Cyclin D3 (green) positive ventro-lateral motor neurons expressing Lim3 (red, arrow). (J) Dorsal Lim1 (red) positive interneurons expressing cyclin D3 (green, arrow). (K) Cyclin D3 is expressed in cells around the lumen (arrow) and in a punctuated pattern in the whole SC. The inlay shows a ventro-lateral part of the spinal cord at a higher magnification. (L) Cyclin D1 is expressed in cells ventrally of the lumen (arrow). Dorsal on the top; Ventral at the bottom. Scale bars: In A, $50 \mu \mathrm{m}$ for A-C; In D, $25 \mu \mathrm{m}$ for D-J; In K, $50 \mu \mathrm{m}$ for K, L. 
The cyclin D3 protein showed a punctuated expression pattern in marginal zone cells (Figure 2D). These cyclin D3 spots were localized exclusively in the cyctoplasm (Figure 2I). The expression of cyclin D3 overlapped in the ventral spinal cord with Lim1 at the forelimb and hind limb levels (Figure 2D-G, arrows) and Islet1/2 (not shown). Additionally, cyclin D3 co-localized with Lim3 (Figure 2I, arrow), a marker of the medial motor neuron column (MMC; Sockanathan and Jessel, 1998). Double staining demonstrated that the motor neurons expressing cyclin D3 at the E12.5 stage, extended axons (Figure 2H, arrow). Additionally, cyclin D3 was expressed in Lim1 positive dorsal interneurons (Figure 1J, arrow).

These results suggest that cyclin D3 is expressed in most, or all, differentiated neurons located in the mantle zone. To address the question of whether this expression of cyclin D3 is extended to other differentiated cells at later stages, the expression was analyzed at the E15.5 stage. At the E15.5 stage, the punctuated pattern of cyclin $\mathrm{D} 3$ protein is present in all or most intermediate and mantle zone cells (Figure 2K), while whole cell bodies were stained in the ventricular zone (Figure 2K, arrow). At the same developmental stage, cyclin D1 was expressed in cells of the ventral ventricular zone (Figure 2L, arrow) while cyclin D2 was absent in the whole spinal cord (not shown).

To prove whether the D-type cyclins were also expressed in distinct subsets of cells in the brain, the expression of D-type cyclins in the midbrain-hindbrain region (Figure 3 ) were analyzed. The results (Figure 3 ) were summarized in Table 2.

In contrast to cyclin D1 and D2, the expression level of cyclin D3 was high in the hindbrain at the E15.5 stage (Figure 3I, arrowhead). Moreover, in the midbrain cyclin D3 was expressed in cells closer to the ventricle than those expressing cyclin D2 (Figure 3H, I, arrows).

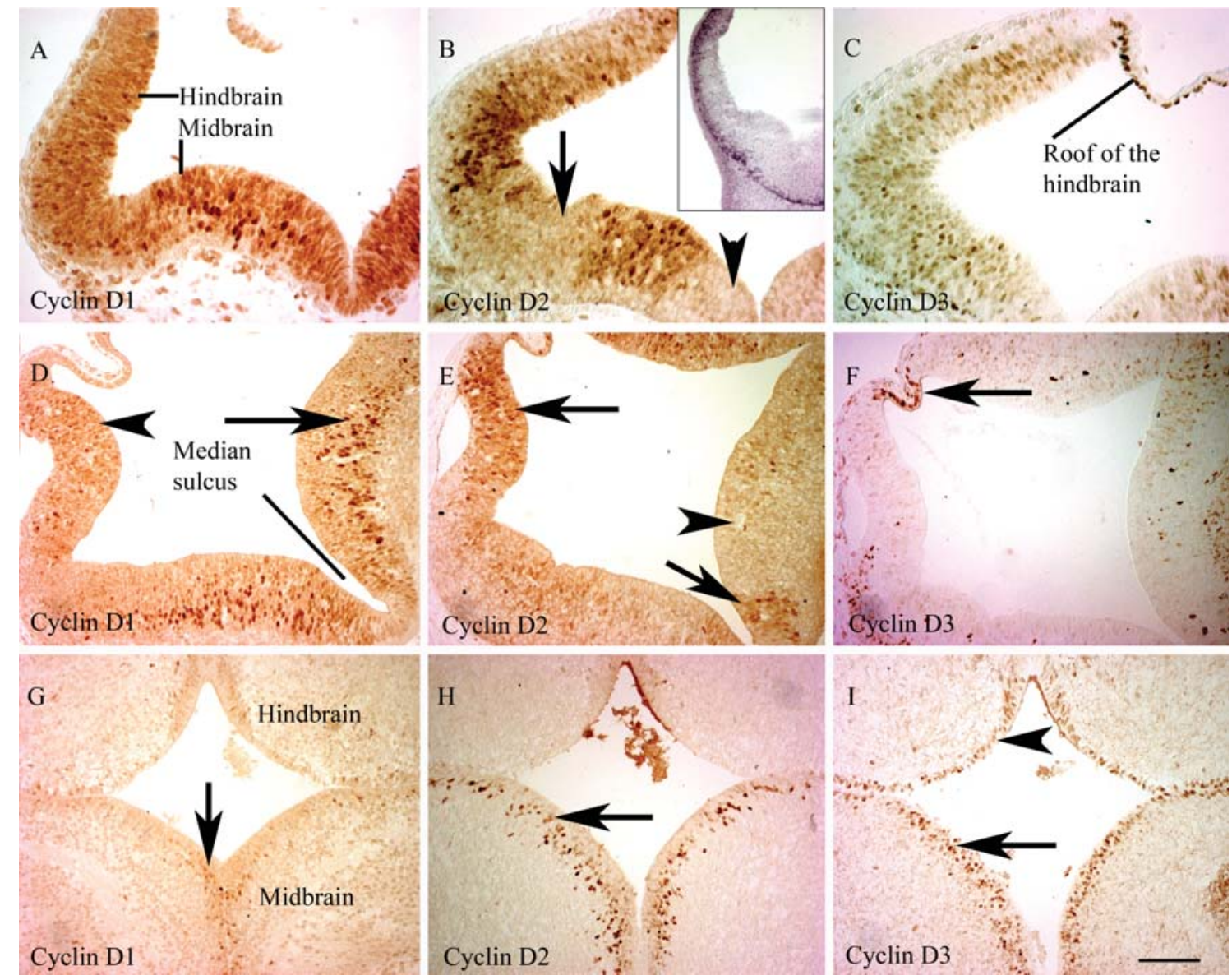

Figure 3 - Consecutive sections through the midbrain-hindbrain region at embryonic stages E10.5 (A-C), E12.5 (D-F) and E15.5 (G-I) showing colorimetric staining of D-type cyclins. (A, D, G) Cyclin D1 protein is detectable in cells of all cycle phases at E10.5 (A), at stage E12.5 mainly in S-phase cells of the midbrain (B, arrow), at weak levels in cells of the hindbrain (D, arrowhead) and in few cells close to the median sulcus at stage E15.5 (G). (B) Cyclin D2 protein is not expressed in a region of the dorsal midbrain (arrow) and around the median sulcus whereas the RNA is present at equal levels in $\mathrm{S}$-phase cells of all regions (inlay). (E, H) At stage E12.5 cyclin D2 is expressed in the hindbrain and around the median sulcus (E, arrows), it is missing in the dorsal midbrain (E, arrowhead) and is up-regulated in the midbrain at E15.5 (H, arrow). (C, F, I) The expression of cyclin D3 at stage E10.5 (C) is reduced to the roof of the hindbrain at stage E12.5 (F) and present again in the whole midbrain-hindbrain region at stage E15.5 (I). Dorsal on the top; Ventral at the bottom. Scale bar: In I, $100 \mu \mathrm{m}$ for A-I. 
Table 2 - Expression of D-type cyclins in the developing mouse mid and hindbrain region. The number of plus symbols indicates the staining intensity $(+++>++>+)$ for each D-type cyclin in the spinal cord at embryonic stages E10.5, E12.5 and E12.5. A bar (-) denotes negligible staining.

\begin{tabular}{lccc}
\hline & \multicolumn{3}{c}{ Cyclin } \\
\cline { 2 - 4 } Embryonic stages & D1 & D2* & D3 \\
\hline E10.5 & & & \\
Midbrain & +++ & $++(\mathrm{do})+++(\mathrm{ve})$ & ++ \\
Hindbrain & +++ & +++ & ++ \\
Roof of the hindbrain & +++ & +++ & +++ \\
Median sulcus & +++ & - & ++ \\
\hline E12.5 & & & + \\
Midbrain & +++ & + & + \\
Hindbrain & ++ & ++ & +++ \\
Roof of the hindbrain & + & ++ & + \\
Median sulcus & +++ & ++ & ++ \\
\hline E15.5 & & & ++ \\
Midbrain & + & ++ & + \\
Hindbrain & - & & + \\
\hline
\end{tabular}

$*$ do $=$ dorsal, $\mathrm{ve}=$ ventral.

\section{Discussion}

At the E10.5 stage, all three D-type cyclins were expressed in most of the spinal cord cells but cyclin D1 and D3 showed higher expression levels in the dorsal half of the spinal cord. Wianny et al. (1998) found that the dorsoventral gradient of the cyclin D1 transcript also occurs in the spinal cord of 7-9 somite-stage embryos. However, in our study we found that at the E10.5 stage cyclin D2 was not missing from the floor plate and also that cyclin D3 was not expressed only ventrally, as was reported for the transcripts of the genes in 7-9 somite stage embryos by Wianny et al. (1998). This may have been due to altered expression patterns of these genes during the time course of spinal cord development and differences in protein and RNA expression patterns. We found that at the E10.5 stage cyclin D3 was expressed at higher levels in the floor and the roof plate than in the other spinal cord cells and that few cells of the mantle zone failed to express cyclin D2. The cyclin D3 expression pattern changed completely at the E12.5 stage. At this stage cyclin D3 was expressed in a punctuated pattern in mantle zone cells. It was possible to attribute this expression to ventral motor neurons and dorsal interneurons by the co-expression of Lim 1 and Lim 3 in these regions. Zhao et al., (1995) have pointed out that spinal cord neurons are generated between the E10 and E14 stages, which suggests that the expression of cyclin D3 in cells of the whole spinal cord at the E15.5 stage has extended to more differentiated neurons. Similarly, Sumrejkanchanakij et al. (2003) reported that cyclin D1 became predominantly cytoplasmatic in cortical cells as they underwent terminal differentiation.
Cyclin D3 is expressed in the absence of CDK4/6 during the differentiation of myoblasts and subsequently in myotubes (Kiess et al., 1995) and is also expressed in compartments of columnar gastrointestinal and stratified squamous epithelia where differentiation takes place (Bartkova et al., 1998). Our results suggest an unknown function of cyclin D3 in differentiating neurons. Sicinska et al. (2003) reported that cyclin D3 knock-out mice are viable and fertile but display lymphoid abnormalities, which could mean that the remaining cyclins can compensate for the loss of function of cyclin D3 in motor neurons. On the other hand, the spastic leg-clasping reflex in cyclin D1 deficient mice argues in favour of an essential role of cyclin D1 during spinal cord development (Fantl et al., 1995; Sicinski et al., 1995).

Various studies have revealed that, apart from their function in the cell cycle, D-type cyclins may be involved in the regulation of the physiological functions of specific neuronal subpopulations (De Falco et al., 2004; Becker and Bonni, 2005; Schmetsdorf et al., 2006). The loss of cyclin D2 in the mouse cerebellum affected the differentiation of stellate and granule interneurons (Huard et al., 1999). We found that cyclin D1 is localized in Lim1-positive interneurons but totally absent in Islet1- and Islet2-positive motor neurons. This could mean that cyclin D1 plays a specific role during differentiation of spinal cord interneurons, although expression is, presumably, transient since we found no up-regulation of cyclin D1 at the E15.5 stage. Alternatively cyclin D1 might play a role during apoptotic cell death of interneurons. Many studies have revealed the upregulation of cyclin D and other cell cycle regulating factors before apoptosis of neuronal cells (Timisit et al., 1999; Fischer et al., 2001; Ino and Chiba, 2001; Katchanov et al., 2001; Liu and Green, 2001; Sumrejkanchanakij et al., 2003; Becker and Bonni, 2004; Becker and Bonni, 2005). Programmed cell death is an integral process in the development of the nervous system (Oppenheim, 1991; Meier et $a l ., 2000)$ and, therefore, an apoptotic function of D-type cyclins in spinal cord and midbrain-hindbrain cells cannot be excluded.

We also found that, similar to the situation in the spinal cord, D-type cyclins were expressed in partially overlapping and different compartments along the dorso-ventral axis of the developing midbrain-hindbrain region. At E10.5 cyclin D2 RNA was expressed at high levels in cells leaving the cell cycle (Figure 3B, inlay) but this expression was not correlated with the up-regulation of the cyclin D2 protein in the same region. This argues in favor of post-transcriptional control of cyclin D2 protein expression in differentiating neurons. Alternatively, high levels of cyclin D2 RNA could be localized in S-phase cells but, however, this would imply that in these neural progenitors cyclin D2 has a function only in the daughter cells during the next cell cycle. The observation that at E15.5 cyclin D2 protein was found at high levels in midbrain cells, obviously leaving the 
cell cycle (Figure 3H, arrow), supports the idea that cyclin D2 is up-regulated in differentiating neurons. However, we found no up-regulation in the hindbrain. In contrast, at the E15.5 stage, cyclin D3 was up-regulated in both midbrain and hindbrain ventricular zone cells. (Figure 3I, arrow, arrowhead)

The question of whether the up-regulation of the distinct D-type cyclins leads to differences in the length of the G1 phase in neural precursor cells has not been addressed as yet. It is known that the total length of the cell cycle of neural precursors changes between the E11 and E16 stages in the telencephalon due mainly to the lengthening of the duration of the G1 phase (Takahashi et al., 1995). Additionally, it has been shown that lengthening of the G1 phase drives neural precursor cells into differentiation (Iacopetti et al., 1999; Calegari and Huttner, 2003; Calegari et al., 2005).

Different functions of the D-type cyclins in the determination of the length of the G1 phase could contribute mainly to the dynamic expression patterns observed in proliferating cells of the nervous system. These roles of D-type cyclins in proliferating cells could be combined with additional functions during the differentiation of specific cell types in the nervous system. Future experiments should elucidate the specific functions of the D-type cyclins during mammalian neurogenesis in proliferating neural precursor cells and differentiating neurons.

In summary, cyclin D1 and cyclin D3 were found to be expressed in differentiating cells at the E12.5 stage. High levels of cyclin D1 protein were expressed in spinal cord ventral interneurons, whereas cyclin D3 protein was expressed in differentiated dorsal interneurons and ventrally in motor neurons. The expression of cyclin D3 in mantle zone neurons was extended to all regions of the spinal cord at the E15.5 stage. The results suggest that cyclins D1 and D3 have specific functions in differentiating neurons and, similarly, that in the developing midbrain-hindbrain region the D-type cyclins are expressed in different subsets of cells.

\section{Acknowledgments}

This work was supported by the Brazilian agencies Ceará State Foundation for Scientific and Technological Development (Fundaçao Cearense de Apoio ao Desenvolvimento Científico e Tecnológico, FUNCAP) and the Brazilian National Counsel of Technological and Scientific Development (Conselho Nacional de Desenvolvimento Científico e Tecnológico, CNPq).

\section{References}

Adams PD and Kaelin Jr WG (1995) Transcriptional control by E2F. Sem Cancer Biol 6:99-108.

Adams PD and Kaelin Jr WG (1996) The cellular effects of E2F overexpression. Curr Top Microbiol Immunol 208:79-93.
Aguzzi A, Kiess M, Rüedi D and Hamel PA (1996) Cyclins D1, D2 and D3 are expressed in distinct tissues during mouse embryogenesis. Transgenics 2:29-39.

Bartkova J, Lukas J, Strauss M and Bartek J (1998) Cyclin D3: Requirement for G1/S transition and high abundance in quiescent tissues suggest a dual role in proliferation and differentiation. Oncogene 17:1027-1037.

Bates S, Bonetta L, MacAllan D, Parry D, Holder A, Dickson C and Peters G (1994a) CDK6 (PLSTIRE) and CDK4 (PSK$\mathrm{J} 3$ ) are a distinct subset of the cyclin-dependent kinases that associate with cyclin D1. Oncogene 9:71-79.

Bates S, Parry D, Bonetta L, Vousden K, Dickson C and Peters G (1994b) Absence of cyclin D/cdk complexes in cells lacking functional retinoblastoma protein. Oncogene 9:1633-1640.

Becker EB and Bonni A (2004) Cell cycle regulation of neuronal apoptosis in development and disease. Prog Neurobiol $72: 1-25$.

Becker EB and Bonni A (2005) Beyond proliferation-cell cycle control of neuronal survival and differentiation in the developing mammalian brain. Semin Cell Dev Biol 16:439-448.

Calegari F and Huttner WB (2003) An inhibition of cyclin-dependent kinases that lengthens, but does not arrest, neuroepithelial cell cycle induces premature neurogenesis. J Cell Sci 116:4947-4955.

Calegari F, Haubensak W, Haffner C and Huttner WB (2005) Selective lengthening of the cell cycle in the neurogenic subpopulation of neural progenitor cells during mouse brain development. J Neurosci 25:6533-6538.

Ciemerych MA, Kenney AM, Sicinska E, Kalaszczynska I, Bronson RT, Rowitch DH, Gardner H and Sicinski P (2002) Development of mice expressing a single D-type cyclin. Genes Dev 16:3277-3289.

De Falco M, Fedele V, De Luca L, Penta R, Cottone G, Cavalotti I, Laforgia V and De Luca A (2004) Evaluation of cyclin D1 expression and its subcellular distribution in mouse tissues. J Anat 205:405-412.

Dyson N (1998) The regulation of E2F by pRB-family proteins. Genes Dev 12:2245-2262.

Ensini M, Tsuchida TN, Belting HG and Jessell TM (1998) The control of rostrocaudal pattern in the developing spinal cord: Specification of motor neuron subtype identity is initiated by signals from paraxial mesoderm. Development 125:969982.

Fantl V, Stamp G, Andrews A, Rosewell I and Dickson C (1995) Mice lacking cyclin D1 are small and show defects in eye and mammary gland development. Genes Dev 9:2364-72.

Fischer SJ, McDonald ES, Gross L and Windebank AJ (2001) Alterations in cell cycle regulation underlie cisplatin induced apoptosis of dorsal root ganglion neurons in vivo. Neurobiol Dis 8:1027-1035.

Hoglinger GU, Breunig JJ, Depboylu C, Rouaux C, Michel PP, Alvarez-Fischer D, Boutillier AL, Degregori J, Oertel WH, Rakic P, et al. (2007) The pRb/E2F cell-cycle pathway mediates cell death in Parkinson's disease. Proc Natl Acad Sci USA 104:3585-3590.

Huard JM, Forster CC, Carter ML, Sicinski P and Ross ME (1999) Cerebellar histogenesis is disturbed in mice lacking cyclin D2. Development 126:1927-1935.

Iacopetti P, Michelini M, Stuckmann I, Oback B, Aaku-Saraste E and Huttner WB (1999) Expression of the antiproliferative gene TIS21 at the onset of neurogenesis identifies single 
neuroepithelial cells that switch from proliferative to neuron-generating division. Proc Natl Acad Sci USA 96:46394644.

Ino $\mathrm{H}$ and Chiba $\mathrm{T}$ (2001) Cyclin dependent kinase 4 and cyclin D1 are required for excitotoxin-induced neuronal cell death in vivo. J. Neurosci 21:6086-6094.

Katchanov J, Harms C, Gertz H, Hauck L, Waeber C, Hirt L, Priller J, von Harsdorf R, Bruck W and Hortnagel H (2001) Mild cerebral ischemia induces loss of cyclin-dependent kinase inhibitors and activation of cell cycle machinery before delayed neuronal cell death. J Neurosci 21:5045-5053.

Kiess M, Gill RM and Hamel PA (1995) Expression of the positive regulator of cell cycle progression, cyclin D3, is induced during differentiation of myoblasts into quiescent myotubes. Oncogene 10:159-166.

Liu DX and Greene LA (2001) Neuronal apoptosis at the G1/S cell cycle checkpoint. Cell Tissue Res 305:217-228.

Lukas J, Bartkova J, Rohde M, Strauss M and Bartek J (1995a) Cyclin D1 is dispensable for G1 control in retinoblastoma gene-deficient cells independently of cdk4 activity. Mol Cell Biol 15:2600-2611.

Lukas J, Bartkova J, Welcker M, Petersen OW, Peters G, Strauss $\mathrm{M}$ and Bartek $\mathrm{J}$ (1995b) Cyclin D2 is a moderately oscillating nucleoprotein required for G1 phase progression in specific cell types. Oncogene 10:2125-2134.

Matsushime H, Roussel MF, Ashmun RA and Sherr CJ (1991) Colony-stimulating factor 1 regulates novel cyclins during the G1 phase of the cell cycle. Cell 65:701-713.

Matsushime H, Roussel MF, Matsushima K, Hishinuma A and Sherr CJ (1994) Cloning and expression of murine interleukin-1 receptor antagonist in macrophages stimulated by colony-stimulating factor 1. Blood 78:616-623.

Meier P, Finch A and Evan G (2000) Apoptosis in development. Nature 407:796-801.

Meyerson M and Harlow E (1994) Identification of G1 kinase activity for cdk6, a novel cyclin D partner. Mol Cell Biol 14:2077-2086.

Oppenheim RW (1991) Cell death during development of the nervous system. Annu Rev Neurosci 14:453-501.

Pfaff SL, Mendelsohn M, Stewart CL, Edlund T and Jessell TM (1996) Requirement for LIM homeobox gene Isl1 in motor neuron generation reveals a motor neuron-dependent step in interneuron differentiation. Cell 84:309-320.

Ross ME and Risken M (1994) MN20, a D2 cyclin found in brain, is implicated in neural differentiation. J Neurosci 14:63846391.

Schmetsdorf S, Gärtner U and Arendt T (2005) Expression of cell cycle related proteins in developing and adult mouse hippocampus. Int J Dev Neurosci 23:101-112

Schmetsdorf S, Gärtner U and Arendt T (2006) Constitutive expression of functionally active cyclin-dependent kinases and their binding partners suggests noncanonical functions of cell cycle regulators in differentiated neurons. Cerebral Cortex 9:1-9.

Sherr CJ (1996) Cancer cell cycles. Science 274:1672-1677.
Sherr CJ and Roberts JM (1999) CDK inhibitors: Positive and negative regulators of G1-phase progression. Genes Dev 13:1501-1512.

Shirasaki R and Pfaff SL (2002) Transcriptional codes and the control of neuronal identity. Annu Rev Neurosci 25:251281.

Sicinska E, Aifantis I, Le Cam L, Swat W, Borowski C, Yu Q, Ferrando AA, Levin SD, Geng Y, von Boehmer $\mathrm{H}$, et al. (2003) Requirement for cyclin D3 in lymphocyte development and T cell leukemias. Cancer Cell 4:451-461.

Sicinski P, Donaher JL, Parker SB, Li T, Fazeli A, Gardner H, Haslam SZ, Bronson RT, Elledge SJ and Weinberg RA (1995) Cyclin D1 provides a link between development and oncogenesis in the retina and breast. Cell 82:621-630.

Sockanathan S and Jessell TM (1998) Motor neuron-derived retinoid signaling specifies the subtype identity of spinal motor neurons. Cell 94:503-514.

Sumrejkanchanakij P, Tamamori-Adachi M, Matsunaga Y, Eto K and Ikeda MA (2003) Role of cyclin D1 cytoplasmatic sequestration in the survival of postmitotic neurons. Oncogene 22:8723-8730.

Takahashi T, Nowakowski RS and Caviness VS Jr (1995) The cell cycle of the pseudostratified ventricular epithelium of the embryonic murine cerebral wall. J Neurosci 15:6046-6057.

Tam SW, Theodoras AM, Shay JW, Draetta GF and Pagano M (1994) Differential expression and regulation of Cyclin D1 protein in normal and tumor human cells: Association with $\mathrm{Cdk} 4$ is required for Cyclin D1 function in G1 progression. Oncogene 9:2663-2674.

Tamaru T, Trigun SK, Okada M and Nakagawa H (1993) Identification of cells expressing a D type G1 cyclin in matured brain: Implication for its neuronal function. Neurosci Lett 153:169-172.

Timisit S, Rivera S, Ouaghi P, Guischard F, Tremblay E, Ben Ari $Y$ and Khrestchatisk M (1999) Increased cyclin D1 in vulnerable neurons in the hippocampus after ischemia and epilepsy: A modulator of in vivo programmed cell death? Eur J Neurosci 11:263-278.

Tsuchida T, Ensini M, Morton SB, Baldassare M, Edlund T, Jessell TM and Pfaff SL (1994) Topographic organization of embryonic motor neurons defined by expression of LIM homeobox genes. Cell 16:957-970.

Weller M, Krautler N, Mantei N, Suter U and Taylor V (2006) Jagged 1 ablation results in cerebellar granule cell migration defects and depletion of Bergmann glia. Dev. Neuroscience 28:70-80.

Wianny F, Real FX, Mummery CL, Van Rooijen M, Lahti J, Samarut J and Savatier P (1998) G1-phase regulators, cyclin D1, cyclin D2, and cyclin D3: Up-regulation at gastrulation and dynamic expression during neurulation. Dev Dyn 212:49-62.

Zhao J, Nornes HO and Neuman T (1995) Expression of Rb, $\mathrm{E} 2 \mathrm{~F} 1, \mathrm{cdc} 2$, and $\mathrm{D}$, and B cyclins in developing spinal cord. Neurosci Lett 190:49-52.

Assistant Editor: Klaus Hartfelder 